\title{
Psychological and pedagogical conditions for the development of students' media competence
}

\author{
*G. S. Tazhenova, Abai Kazakh National Pedagogical University, Almaty, Kazakhstan, \\ karakulovagulsara@bk.ru \\ L. T. Makulova, Taraz State Pedagogical University, Taraz, Kazakhstan \\ Zh. K. Adilbekova, M. Auezov South Kazakhstan University, Shymkent, Kazakhstan \\ M. K. Sarsembayeva, M. Kh. Dulati Taraz Regional University, Taraz Kazakhstan \\ Zh. Mykhanova, M. Kh. Dulati Taraz Regional University, Taraz Kazakhstan \\ *Corresponding Author
}

\begin{abstract}
Today, taking into consideration the both positive and negative sides of information, it is necessary to develop a person who is able to defend himself from the latter. Especially, against the backdrop of a real epidemic in the center of China, when the rest of the world, according to the world health organization (WHO), has erupted the spread of an excessive amount of information about the coronavirus, including reliable, but mostly fake. In this regards, it becomes very important to develop media literacy among young people. Hence, the paper is devoted to the development of students' media competence which is relevant today in the field of education and upbringing. The authors consider 'media competence' will develop through media education in the sense of working with sources of information, learning to search for necessary, useful information, as well as to distinguish between true and false information. In this case, a competent person is characterized as a person who can correctly analyze media products, choose what he or she needs from the flow of information, and knows how to avoid the negative effects of harmful, inhumane materials. Therefore, the authors believe that conditions should be created for the effective solution of the problem raised in the pedagogical process of the university, and as one of them offers scientifically based psychological and pedagogical conditions for the development of students' media competence. In our study, experimental work was organized on the basis of Abai Kazakh National Pedagogical University and Taraz Pedagogical University. To conduct the experiment, two groups of 188 students majoring in "Pedagogy and Psychology" and "Pedagogy and Methodology of Primary Education" were organized: experimental and control groups. The paper presents some fragments from the results of practical testing of psychological and pedagogical conditions.
\end{abstract}

Keywords: information security; Internet; media; media education; media competence; psychological and pedagogical conditions..

Received: 19.11 .2020

Accepted: 16.12 .2020

Published: 09.01.2021

\section{INTRODUCTION}

It is considered to be very topical to develop individual's media literacy as the ability to understand and evaluate the information disseminated by the media, as well as reading, writing literacies and to protect young people from anti-human and negative influences from information in XXI century (Treumann et al., 2007). A fairly impressive example of the negative impact of information is the beginning of this year, when the world was hit by a flurry of various kinds of information about the mysterious coronavirus discovered in China and officially named COVID-19. Due to this even, all education system has changed (Arlinwibowo et al., 2020; Pratama et al., 2020).

At the same time, the implementation of systematic pedagogical measures aimed at preventing the negative, dominant influence of media products in the educational process of higher education, the search for methods, tools, forms of media competence and in-depth study of scientific and practical basis are important objectives (Gapski, 2005). There is no doubt that this problem will be solved as a result of proper media education, which will contribute to the development of media literacy among young people (Silverblatt \& Enright Eliceiri, 1997).

In this regard, we believe that the effective solutions and conditions to this issue should be created in the pedagogical process of the university. In our work we set the objective to justify and practice the psychological and pedagogical conditions for the development of students' media competence (Mokshein et al., 2015). 


\section{MATERIALS AND METHODS OF RESEARCH}

There are many opportunities to give media education to students in higher educational institutions in the Republic of Kazakhstan. Nevertheless, there is no doubt that there is a need for education to prepare young people and students for the conscious use of media. One of them is the need to look for conditions to develop students' media competence. This is one of the main objectives of our research. This study is based on qualitative research. Experimental research work was organized at Abai Kazakh National Pedagogical University and Taraz Pedagogical University. To conduct the experiment, there were two groups that consisted of 188 students majoring in "Pedagogy and Psychology" and "Pedagogy and Methodology of Primary Education". There were 95 students in the experimental group and 93 students in the control group.

In the process of professional training and creating a set of pedagogical conditions that help to increase the level of university students' media competence: we have taken into consideration the social order of society to higher professional schools; features of the educational process in the university and the possibility of using them to develop the studied skills; leading idea of competence approach (Weber, 1994).

In connection with the above, we have identified the following set of pedagogical conditions to develop students' media competences:

- Implemening the development of student's media competence in combination with methodological activity, competence, axiological, semiotic approaches;

- development of students' critical attitude to the consumption of media products.

- knowing the methods of media manipulation on mind;

- technological support of the process of students' perception and understanding of media texts.

The first condition provides the methodological, the second - psychological, the third and fourth methodological, technological solutions to the issues. All of them are designed to effectively address the research problem in close cooperation with each other (Turgunbaeva \& Tazhenova, 2018).

The effective solution of the object we are studying depends on the correct determination of its methodological approach. By analyzing the theoretical and methodological basis of science, we consider the unity of competence, action, axiological and semiotic bases will increase the efficiency. The brief description of these methodological approaches is given in the following.

The analysis of the scientific literature in the field of media education pays special attention to the competence approach. The competence is guided by the ability to focus on knowledge, the development of a person's ability to act in different problem situations, rather than a set of mastered information.

Khutorskoy (2003) considers the concept of "competence" as a set of interrelated human qualities which depend on a certain range of objects and processes and are necessary for their high-quality and productive action (Umberto, 1976).

During the study by analyzing the scientific and pedagogical views, we come to the conclusion that competence is a set of integrated personal qualities that allow us to effectively and creatively solve problems and objectives that arise in real life situations using the previous knowledge and experience (Absatova \& Tazhenova, 2016).

This competence approach contributes to the development of students' ability to evaluate any information, effectively support student's curiosity in the analysis of information, a creative approach, the organization of regular analysis and reflection in the development of media competence (Agus \& Samuri, 2018).

The next step we have chosen is the action of the competency-based approach. Action is a way of human interaction with the world. A person can be changed creatively by mastering the nature and environment around him. Thus, he forms himself as a business, creative subject, and makes mastered natural environment as the object of his activity.

The famous psychologist Leontlev (1974) explains that the development of the achievements of human culture is the further improvement of its achievements through action. A scientist defines an operation as a part of an action, by another words as "a way to perform an action in real situations" (Leontiev, 1974:47).

According to Rubinstein (1958), human activity is recognized as 'the principle of the unity of the psyche and action, suggesting that it can be regarded as the essence of psychology' (Rubinstein, 1958:233). According to Smirnov (2005), the action of competence approach is the recognition and transformation of the environment through the actions of the individual, the discovery of the integrity of the object and its mechanisms. 
A competent approach to the development of media competence effectively updates the subjective positions of students. In order to master media competence, a student must be in a state of active cognitive activity or subjectivity.

The practical manifestation of the above: the organization of media education in the context of action - the emergence of certain units of action in students, the interaction of teachers and students who are the subject of media education.

We selected the following axiological competence approaches in the development of students' media competence (Kagan, 1997; Langle, 2007; Ravkin, 1995; Rozov, 1992; Tugarinov, 1960, etc.) the researchers associate with the concepts of values, worldview, human life principles.

The axiological approach in the learning process recognizes the individual as a participant in the process of the development of value behavior.

The axiological competence approach is the perception of the participation of the individual in the process of developing value-based behavior in the educational process.

The analysis of the scientific literature by Nikitina (2011), Smirnova (2004), Orlova (1994) and others allow us to understand the axiological approach, a way of organizing interaction, which leads to targeted actions that motivate subjects, educational process to achieve media competence. This is an approach that is used in the process of teacher training to increase the level of media competence of university students, to engage students to join creative activities in order to solve media problems.

Guided by the axiological competence approach in the process of developing a media competence, the teacher provides an equal opportunities for all students, regardless of their specific learning abilities, to express their opinions, suggestions and criticism; liberation of students from emotional and intellectual stress, stress and insecurity; we believe that the teacher's refusal from the role of tyranny is an attempt to remove the restricted areas for discussion.

The role of the semiotic competence approach is special that we are studying in the effective solution of the problem. The scientific concept of 'semiotics' comes from the Greek word 'family' - a sign, a symbol. Umberto (1976), one of the most famous researchers of modern semiotics, in his work states that semiotic studies all the things that can be considered iconic.

The founder of semiotics, the American logician and philosopher Peirce (1977), defined and classified symbols, objectives, functions of a new field of science. His successor Morris (1977) defined the structure of semiotics.

Semiotics is a system of symbols used to convey various messages and information. It includes the language of people, various information and social processes, the development of culture and art (Menlibekova, 2001). The system of sign makes a person's thinking process more productive and accelerate cognitive.

Symbols and ideas are information carriers and the main building material of the text. Therefore, this competence approach is guided by on the analysis of advertising and videos in the media. In particular, it plays a significant role in determining advertising characters that help to understand the inner philosophy.The ability to identify backgrounds in media products is a sign of media competence.

The next pedagogical condition is the students' choice of understanding the methods of controlling consciousness in the media. The subjects of mass informational consciousness: media texts, symbols, commercials, videos, etc. based on the characteristics of the human psyche that shape their impact on the media.

The development of scientific thought about the potential to dominate the consciousness of the products of the media in the twentieth century (in the 1920s), the American researcher Lippman (2004), who came up with the idea that news is created in a certain way and argued in his work that the superficial media's assessment of events leads to the development of stereotypes and 'legends' in the mass consciousness and forces people to perceive and evaluate the world in this distorted way '(Lippman, 2004: 154).

Even today, pre-election media technologies and advertising practices are often used to influence the consciousness in transmitting an information. The effect is not open, but hidden.

The power of the dominant influence of consciousness is such that it puts the oppressed person in a position where he wants to do certain things, even if they are ineffective.

In our opinion, the control of consciousness is a psychological approach, which deliberately forces a person to take certain actions against his intentions. Therefore, we believe that the search for ways to protect information from the domination of the human mind should be considered in the context of the development of media competence. This is because media competence includes the quality of a person, such as the competent use of information products, which means knowing how to protect himself. Mastering these mechanisms is the role of media pedagogy. 
The next condition is the development of students' critical attitude to the consumption of media products (Mohd Najid et al., 2019). Today, the media is the 'fourth power' that propagates individuals' the model of behavior and social values. Hence, it is required to develop young people's critical thinking as one of the measures to prevent from making mistakes in the use of media products.

A well-known psychologist Halpern (2000) argues and expresses his opinion on that "the critical thinking is the use of cognitive techniques or strategies that increase the chances of getting the expected result, a thinker uses effective skills to achieve objectives and a particular type of event.

Cluster (2002) begins with a critical thinking, asking questions, and identifying issues that need to be addressed, considering critical thinking to be social and independent thinking. It means that convincing evidence is created through critical thinking. The author notes that information is not the end point of critical thinking, but the starting point (Clusters, 2002).

Cluster considers a critical thinking to be a social and an independent thinking and it is considered that it begins from an asking question and determining a problem. This means that a critical thinking provides a compelling evidence (Eken, 2005). The author emphasizes that information is not the end of critical thinking, but the starting point.

Following the direction of the development of critical thinking, the French media educator Gonne (1994) considers that the most important thing is that the student must be a free, open citizen of a democratic society with the ability to think autonomously (Gonne, 1994: 4). A British Ferguson (2000) also gives a similar view to this evidence (388 p), Buckingham \& Sefton-Green (1977) agrees with them that teachers should give students the opportunity to establish a connection between personality and politics, therefore, pays much attention to prepare them for an active civic view in a wide range of social sphere (Buckingham, 1977: 218)

We believe that critical thinking in media education can lead to errors, misrepresentations, suspicions, etc. in the perception of media information, as well as, identification of various elements, a multifaceted analytical process aimed at making the right decisions in the consumption of information.

We believe that critical thinking in media education can lead to errors, misrepresentations, suspicions, etc. in the perception of media information. Identification of various elements, a multifaceted analytical process aimed at making the right decisions in the consumption of information.

Critical analysis of media text is a thought operation that determines the properties and relationships of its individual elements.

The fourth condition that increases the effectiveness of the research problem is the technological support of the process of students' perception and understanding of media texts.

A critical analysis of the media text is a mental operation that determines the properties and relationships of its individual elements.

The fourth condition that increases the effectiveness of the research problem is the technological support of the process of perception and understanding by students of media texts.

Technological support of the process of perception and understanding of media texts - means the effective use of systems, methods and technologies that make this process effective.

To develop a media competence in our work and the reason for taking this competence approaches in lectures, seminars to develop critical thinking issues of audience, different views and opinions, create conditions to students to make their own opinions, decisions, conclusions, to consume media products through paired and group analysis: analyze media texts, such as deep understanding of the idea, listen to different points of view, the ability to compare, to promote responsibility to develop one's own opinions will be implemented to solve pedagogical problems.

Therefore, we came to the conclusion that the integration of competence, action, axiological competence approaches will allow to effectively address the goals and objectives of the study in shaping the quality of the person we are looking for, based on the guiding principles of students' media competence, activism, creativity and critical thinking, human values such as tolerance, empathy, reflection in the consumption of media products.

Summarizing the above, we conclude that the media raises the capacity to understand and resist the dominant influence of consciousness as a result of the implementation of the proposed conditions to develop students' media competence which will be able to gain knowledge about the media, understand and use the terms; develop the ability to competently consume media products through orientation in the media space, critical thinking; effective use of new methods and technologies that increases the ability to analyze media information.

Our experimental work was organized on the basis of the Kazakh National Pedagogical University named after Abay and Taraz Pedagogical University. Two groups of 188 students majoring in 'Pedagogy and Psychology' and 'Pedagogy and Methodology of Primary Education' were organized to conduct the experiment - experimental and control groups. 
The following diagnostic methods were selected as the main methods of collecting primary data:

1. 'Which source of information do you prefer when getting acquainted with new information?' author's questionnaire.

2. Fetiskin's et al (2002) 'Knowledge of Information Technology' method 'Do you know about the world of media?' was used with modification.

3. 'How literate are you in consuming media products?' questionnaire.

4. Lukyanova's (2011) method of diagnosing the level of motivation 'Fight against cyber extremism'.

As the length of the article does not allow, we decided to give only some conclusions from these diagnoses.

The result of 'How literate are you in consuming media products?' is given below in (Figure 1) as the indicators of media competence of the groups participating in the survey.

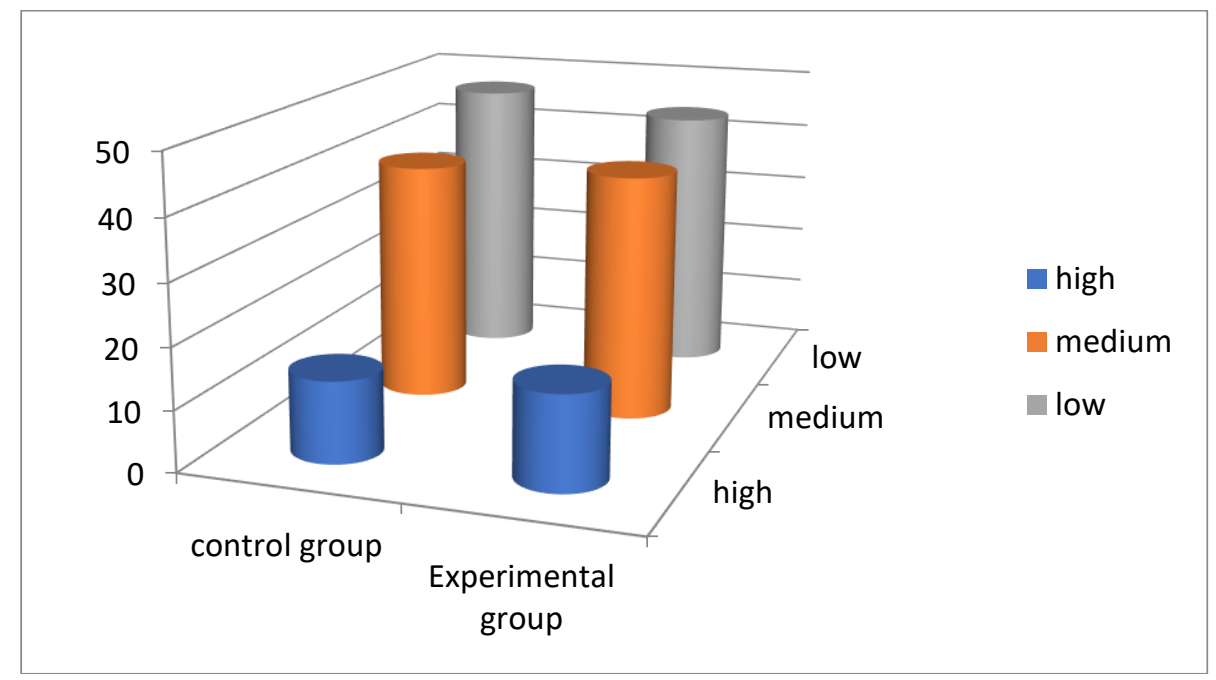

Figure 1. In the control and experimental groups, 'How literate are you in consuming media products?' the relative percentage of the survey (\%)

As we read in the table above, It should be noted that $13.45 \%$ of students have a high level in the control group, $39.64 \%$ have an average level, and $46.89 \%$ have a low level. In the experimental group, $15.56 \%$ had a high level, $40.59 \%$ had a medium level, and $44.04 \%$ had a low level. It is also possible to develop the appropriate skills with the help of systematic work.

The results of Lukyanova's (2011) survey in 'Methods for diagnosing the level of motivation to combat cyber extremism' with student were given below.

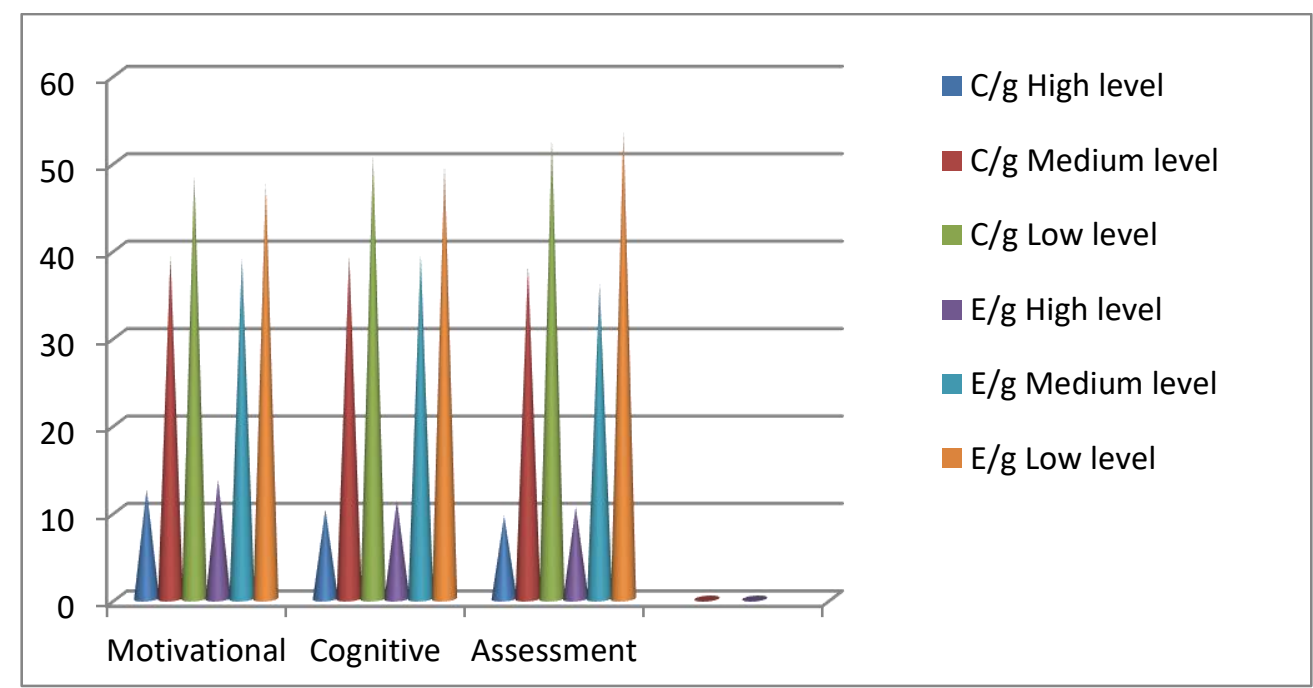

Figure 2. The initial level of comparative results of the survey conducted by the method of Lukyanova 'Methods for diagnosing the level of motivation to combat cyber extremism' in control and experimental groups (\%). 
According to the obtained results, in control group 12.5\%, in experimental group $13.6 \%$ had a high level of motivation and in control group $10.2 \%$ students, in experimental group $11.2 \%$ of the students' showed higher cognitive level, $9,5 \%$ in control group and $10.5 \%$ of the students in the experimental group showed a high level of assessment.

Thus, $39,1 \%$ of students in control group, $39 \%$ of students in experimental group had middle cognitive level while $39.2 \%$ of students in control group, $39.3 \%$ of students in experimental group show the same middle cognitive level and $38 \%$ of students in control group, $36 \%$ in experimental group showed the average level of assessment.

In addition, $48.4 \%$ of the control group, $47.4 \%$ of the experimental group showed a low level of motivation while $50.6 \%$ of the control group and $49.5 \%$ of the experimental group had a low cognitive level, $52.5 \%$ of the control and $29.5 \%$ experimental groups had a low assessment level.

According to the results of a survey of control and experimental groups, students showed a high and medium level of resistance to cyber-extremism. This means that some students are interested in counteracting the activities of various extremist groups on the Internet and some students are interested in taking action on this issue, but in some respects they are indifferent.

Summing up the results of the defining experiment, it was determined that it is necessary to carry out special preparatory work to develop students' media competencies. This was done by conducting a special course according to the content and methodology given in the previous chapter of our work.

The total volume of the elective course 'Fundamentals of Media Education', designed for students majoring in pedagogy and psychology, consist of 2 credits, 30 hours are for classwork for 15 weeks. Theoretical lessons consist of 15 hours, practical lesson (seminar) - 15 hours; TSIS - 30; SIS- 30 hours and it is total 90 hours.

In conducting the proposed author's elective course, it is targeted at defining the issue to prove the effectiveness of the described psychological and pedagogical conditions to develop students' media competence.

\section{RESULTS}

In the conducted experimental work, the following didactic methods were chosen, which contribute to the development of media competence through media education as vocabulary: lectures, conversations, discussions, conversations; visualization: visual analysis of media texts, illustrations, videos, advertisements;

Media - content analysis of products, problem analysis; solving creative tasks based on media materials; research (search): students' independently search for interesting materials from sources of information and present the material; reproductive: the development and use of various exercises and tasks by the teacher on the basis of media material to train students' the necessary skills; interactive methods of modern pedagogical technologies; special methods of analysis of media products.

When using these methods, students' learning activities include: descriptive (narrate the content by naming the participants and events); personality (describe emotions, attitudes, memories related to the media text); expert (analyze the language, structure of the media text from a multifaceted point of view); classification (place of the work in the historical context); explanatory (development of views on the media text); evaluation (formulation of the advantages of media text on the basis of defined criteria);

During the experiment, the interactive methods of 'Development of critical thinking through reading and writing' (RWCT) technology were widely used. In particular, the methods of 'I know, I want to know, I learned', 'Insert', 'Question to the author', 'Graphic organizers', 'Conceptual table', 'Grouping', 'POPS', 'RAFT' analyzed media products and had influenced to understand the background.

In addition, the following special methods of information product analysis were effectively used.

Media biography method. This method helps to determine students' experiences of consuming media products. The following system of questions is used to determine this issue:

1. What media products were important to you?

2. What was the attitude of your family towards media? Were there certain rules?

3. Did the school talk about media?

4. Were media products used?

5. How do you assess your media consumption?

6. How do you assess your media literacy?

7. In what area do you want to develop your media competence?

The students' answers to these questions provide information about the consumer biography of media products. This data will allow us to design further work in the field of media literacy. 
The method to critically analyze advertising is carried out in the following order. First, students are offered to watch the commercial 3 times (20 seconds with a 3-minute break). Then, by analyzing the video, they will be able to correctly determine the purpose of the advertising message, to fairly highlight the motives of the message.

Emphasizing the use of suggestive technologies, the author of the media product persuades the consumer (suggestion), thereby determining the means of its psychological impact on the person, determines the impact on the consumer by analyzing the emotional impact of color and shape in advertising. This method can achieve a high level of critical perception of advertising.

The selected parameters of didactic support of practical and experimental work are the general and conceptual basis of the pedagogical experiment - methods, principles, forms, methods, sequence, functions of the educational process of development of media competence, as well as students reflected in the special author's course program. It also gives an idea of the content of the educational-methodical complex on the development of media competence and includes specific goals, objectives, forms, methods, tools, exercises and creative tasks aimed to develop students' media competence.

Thus, it is concluded that the system of lectures, seminars and practical classes aimed at developing media education, media competence allows students to get acquainted with theories and concepts in accordance with the history and stages of the development of media education, analyze media texts, understand the purpose of the media.

At the end of the formative experiment, the diagnostic methods used during the diagnostic experiment to diagnose the development of students' media competence were repeated.

The results of Lukyanova's (2011) survey 'Methods for diagnosing the level of motivation to combat cyber extremism' were as follows.

Table 1. Comparative results of Lukanova's survey 'Methods for diagnosing the motivation level to combat cyber extremism' before and after practice (\%)

\begin{tabular}{|c|c|c|c|c|c|c|c|c|c|c|c|c|}
\hline \multirow{4}{*}{$\begin{array}{lr}\text { Development } & \text { of } \\
\text { incentives } & \text { to } \\
\text { combat } & \text { cyber } \\
\text { extremism } & \\
\end{array}$} & \multicolumn{6}{|c|}{ Before the experiment } & \multicolumn{6}{|c|}{ After the experiment } \\
\hline & \multicolumn{3}{|c|}{ Control group } & \multicolumn{3}{|c|}{ Experiment group } & \multicolumn{3}{|c|}{ Control group } & \multicolumn{3}{|c|}{ Experiment group } \\
\hline & \multicolumn{6}{|c|}{ Levels } & \multicolumn{6}{|c|}{ Levels } \\
\hline & high & mid & lon & high & mid & low & high & mid & low & high & mid & low \\
\hline motivational & 12,5 & 39,1 & $\begin{array}{l}48, \\
4\end{array}$ & 13,6 & 39 & 47,4 & 51,7 & 36 & $\begin{array}{l}12, \\
3\end{array}$ & 53,4 & 36 & $\begin{array}{l}10, \\
6\end{array}$ \\
\hline cognitive & 10,2 & 39,2 & $\begin{array}{l}50, \\
6 \\
\end{array}$ & 11,2 & $\begin{array}{l}39, \\
3\end{array}$ & 49,5 & 51,5 & 37 & $\begin{array}{l}11, \\
5\end{array}$ & 51,5 & 37 & $\begin{array}{l}11, \\
5\end{array}$ \\
\hline Assessment & 9,5 & 38 & $\begin{array}{l}52, \\
5\end{array}$ & 10,5 & 36 & 53,5 & 48,6 & 38 & $\begin{array}{l}13, \\
4\end{array}$ & 49,6 & 38 & $\begin{array}{l}12, \\
4\end{array}$ \\
\hline Average value & $\begin{array}{l}\text { тоб } \\
\text { b }\end{array}$ & $\begin{array}{l}38,7 \\
6\end{array}$ & $\begin{array}{l}50 \\
5\end{array}$ & $\begin{array}{l}11,7 \\
6\end{array}$ & $\begin{array}{l}\text { 38, } \\
1\end{array}$ & $\begin{array}{l}50,1 \\
3\end{array}$ & 50,6 & 37 & $\begin{array}{l}12, \\
4\end{array}$ & 51,5 & 37 & $\begin{array}{l}11, \\
5\end{array}$ \\
\hline
\end{tabular}

According to the modified method 'Diagnosis of the level of motivation to combat cyber extremism' between the control and experimental groups, we used the 'Student's T-criterion for independent selection' to determine the difference between the levels of knowledge about the media, media products, media competence (Table 23).

Table 2 Comparative results of the survey conducted by Lukanova on 'Methods for diagnosing the level of motivation to combat cyber extremism' pre-practice and post-practice level (\%)

Table 2. According to the 'Student's T-criterion for independent selection'

\begin{tabular}{|c|c|c|c|c|c|c|c|c|c|c|c|c|c|c|}
\hline \multirow{4}{*}{ 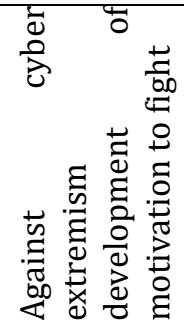 } & \multicolumn{6}{|c|}{ Before the experiment } & \multicolumn{6}{|c|}{ After the experiment } & \multirow{2}{*}{$\begin{array}{l}\text { Control } \\
\text { gr. } \\
\text { Tempo }\end{array}$} & \multirow{2}{*}{$\begin{array}{l}\text { Exper. } \\
\text { Gr. } \\
\text { Tempo }\end{array}$} \\
\hline & \multicolumn{3}{|c|}{ Control group } & \multicolumn{3}{|c|}{$\begin{array}{l}\text { Experimental } \\
\text { group }\end{array}$} & \multicolumn{3}{|c|}{ Control group } & \multicolumn{3}{|c|}{$\begin{array}{l}\text { Experimental } \\
\text { group }\end{array}$} & & \\
\hline & \multicolumn{3}{|c|}{ деңгейлері } & \multicolumn{3}{|c|}{ деңгейлері } & \multicolumn{3}{|c|}{ деңгейлері } & \multicolumn{3}{|c|}{ деңгейлері } & $\mathrm{P}$ & $\mathrm{p}$ \\
\hline & $\mathrm{M}_{1}$ & $\mathrm{~m}_{1}$ & $\sigma 1$ & $\mathrm{M}_{1}$ & $\mathrm{~m}_{1}$ & $\sigma 1$ & $\mathrm{M}_{2}$ & $\mathrm{~m}_{2}$ & $\sigma 2$ & M2 & $\mathrm{m} 2$ & $\sigma 2$ & & \\
\hline M & 1,8 & 0,34 & 2,1 & $\begin{array}{l}1,8 \\
4\end{array}$ & 0,9 & $\begin{array}{l}2,7 \\
3\end{array}$ & 1,1 & 1 & 0,1 & 1,9 & 0 & 1,9 & 0,440 & $\begin{array}{l}p=0,05 \\
0,275\end{array}$ \\
\hline $\mathrm{T}$ & 0,5 & 0,44 & 0,1 & $\begin{array}{l}0,5 \\
6\end{array}$ & 1,2 & $\begin{array}{l}0.6 \\
3\end{array}$ & 0,9 & 0 & 0.9 & 0 & 0 & 0 & 0,318 & $\begin{array}{l}p=0,05 \\
1.604\end{array}$ \\
\hline
\end{tabular}




\begin{tabular}{|l|l|l|l|l|l|l|l|l|l|l|l|l|l|l|}
\hline & & & & 1,2 & & 3.3 & & & & & & & 0,110 & $\mathrm{p}=0,05$ \\
Б & 1,2 & 0.76 & 2 & 6 & 2,1 & 7 & 2 & 1 & 1 & 1,9 & 0 & 1,9 & & 0,452 \\
\hline
\end{tabular}

Checking the reliability of the results of our research was carried out using the criterion 'Chisquare'. Here is the formula for calculating the size:

$$
\chi_{n}^{2}=\sum_{i=1}^{n} \frac{\left(O_{i}-E_{i}\right)^{2}}{E_{i}}
$$

To determine the reliability of the differences between the actual and expected frequencies, it is necessary to compare the value of $\chi^{2}$ crit with the critical value of this criterion $\chi 2$ crit. value.

The reliability of the differences can be inferred only when the value of $\chi^{2}$ эксп exceeds the critical

In this case, $\chi 2 \exp =482,071$, and $\chi 2$ crit $=447.68$. Therefore, the experimental value exceeded the critical value. 0.05 .

Therefore, control and the level of validity between the experimental groups is expressed as $p=$

The final calculations show an increase in the results in the experimental group compared to the control group. The results of the formative experiment show that in the course of professional training students are provided with a set of theoretical and practical knowledge on 'media', 'media education', 'media literacy', 'consciousness', 'media competence' (European Parliament resolution (2008).

If we look at the previous and final results of the survey of control and experimental groups, there is a slight change in the answers of students in the control group, and there is a significant improvement in the results of students in the experimental group.

The final result of the formative experiment required the release of growth dynamics of the components of media competence.

In 2.1 part of our work, the figure shows a graphical representation of the identified data on the indicators of motivational, cognitive and evaluative components of media competence.

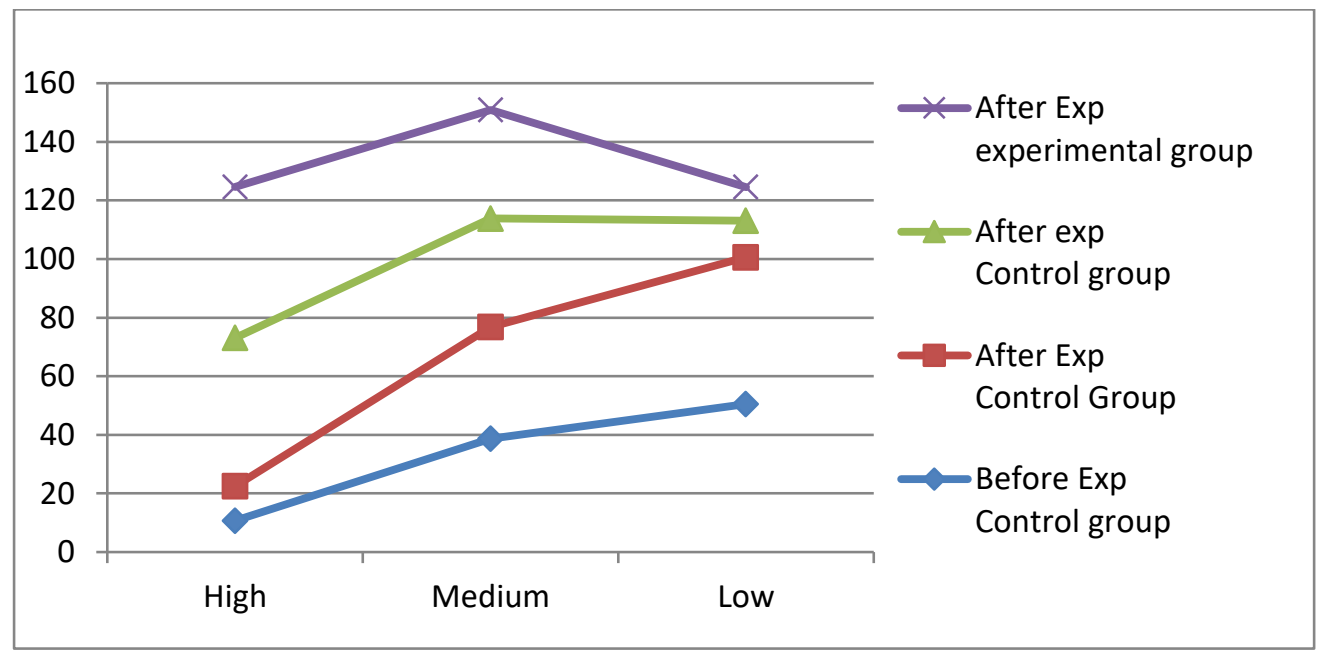

Figure 3. Students' before and after the experiment of media competence level's ndicators (\%)

The figure shows an increase in the results in the experimental group compared to the control group. The results of the formative experiment show that in the course of professional training students are provided with a set of theoretical and practical knowledge on 'media', 'media education', 'media literacy', 'consciousness', 'media competence'.

To confirm the results, we compared the mean values of the t-criterion Student's size using the following formula:

$$
t=\frac{M_{1}-M_{2}}{\sqrt{m_{1}^{2}+m_{2}^{2}}}
$$




$$
\begin{aligned}
& t_{3 n_{n}}=\frac{|\bar{x}-\bar{y}|}{\sqrt{n_{1} \cdot D_{x}+n_{2} \cdot D_{y}}} \cdot \sqrt{\frac{n_{1} \cdot n_{2}}{n_{1}+n_{2}} \cdot\left(n_{1}+n_{2}-2\right)} \\
& M_{1} \text { - is the arithmetic mean of the first relative set, } \\
& m_{2} \text { is the arithmetic mean of the second set, } \\
& m_{1} \text { is the error of the first arithmetic mean, } m_{2} \text { is the error of the second arithmetic } \\
& \text { mean. }
\end{aligned}
$$

As shown above, since the value of the calculated criterion is higher than the critical value, we see that the data observed in the experimental group were less than the $t$-critical value of the t-empirical value. That is, we see that the experimental group is more inaccurate than the control group.

\section{DISCUSSION}

The competent approach, which is used on the basis of university determined the way to prevent from media influence on consciousness - the development of media competence on the issue of consciousness is not only understanding the need for education but develop self-improvement abilities, skills, knowledge in this area contributed to the development of qualities and motivational goals.

The use of a proactive approach to develop students' media competence, the orientation of students to active, productive, individual and group work, the choice of active teaching methods, reflected in the diversity of pedagogical work, the diversity of student work, reduced the monotony of lessons and increased student interest.

One of the objectives of the study was to develop media competence, the content which allowed future professionals to increase their motivation to consume media products and gain theoreticalpractical knowledge and skills related to the media. It has a positive effect on skills development to apply the acquired knowledge in practice.

The special methods used during the author's course to develop students' knowledge of the media and skills in the competent use of media products contributed to the development of their critical thinking. In turn, the students' ability to think critically showed the development of the necessary competencies as a media consumer. The work carried out in this direction during the experiment showed the effectiveness of technologicalization of the process to develop students' media competencies.

\section{CONCLUSION}

The conclusion proves that the research objectives have been solved, the proposed psychological and pedagogical conditions have been chosen correctly. The three main stages proposed in the experimental program ('diagnostics - course - diagnostics') proved to be the most logical solution in the context of the research objectives. These stages allowed to analyze the changes in the indicators and criteria of media competence of the subjects at all times of the experiment, and the formative phase of the experiment showed an increase in developing all components of media competence. We are grateful to the leadership and staff of the Kazakh National Pedagogical University named after Abay and Taraz State Pedagogical University for the great support of our experimental work.

\section{REFERENCES}

Absatova, M. A., \& Tazhenova G. S. (2016). The description types of competences in Kazakhstan's scientists' pedagogical research. Kazakh National Pedagogical University named after Abai. Bulletin 'Pedagogical Sciences' series, 3 (51), 203-207.

Agus, R., \& Samuri, S. M. (2018). Learning Analytics Contribution in Education and Child Development: A Review on Learning Analytics. Asian Journal of Assessment in Teaching and Learning, 8, 36-47. https://doi.org/10.37134/ajatel.vol8.4.2018.

Arlinwibowo, J., Retnawati, H., Kartowagiran, B., \& Kassymova, G. K. (2020) Distance learning policy in Indonesia for facing pandemic COVID-19: School reaction and lesson plans. Journal of Theoretical and Applied Information Technology, 98(14), 2828-2838.

Buckingham, D., \& Sefton-Green, J. (1997). Multimedia Education: Media Literacy in the Age of Digital Culture. In: Kubey, R. (Ed.). Media Literacy in the Information Age. Transaction Publishers, $290 \mathrm{p}$

Clusters, D. (2002). What is critical thinking. № 29. Retrieved from: http://rus.1september.ru/article.php?ID=200202902. 
Eken, A. N. (2005). Critical thinking and new types of literacy: collection / composition. CSL, 23-36

European Parliament resolution. (2008, December 16) on media literacy in the world of digital technologies (2008/2129 (INI) [electronic resource]. Available at: https://op.europa.eu/en/publication-detail/-/publication/aa25676b-a98c-4f30-b813698fa076d035/language-en

Ferguson, A. (2000). Experience of the history of civil. ROSSPEN. University Library of Political Science), 389

Fetiskin, N. P., Kozlov, V.V., \& Manuilov, G. M. (2002). Socio-psychological diagnosis of the development of personality and small groups. Institute of Psychotherapy Publishing House, 490

Gapski, H. (2005). European examples for the promotion of visual competence in the media world. Projects, initiatives and ideas for North Rhine-Westphalia. Retrieved from: urn:nbn:de:bsz:mh39-36585

Gonne, J. (1994). Press in school: development of active civil position. Children's and youth amateur media: theory and practice. UNPRESS, 10-13.

Halpern, D. (2000). Psychology of critical thinking. Peter, 503

Kagan, M. S. (1997). Philosophical theory of values. Petropolis, 205

Kenzhebekov, B. (2004). Theoretical basis of specialist's professional competence. Primary school, №7, 3-7.

Khutorskoy, A. V. (2013). Competent approach to training. Scientific-methodical manual. Eidos Publishing House

Khutorskoy, A. V. (2003). Key competencies: design technology. National education. №5.

Langle, A. (2007). Emotions and existence. Publishing House of the Humanitarian Center, 332

Leontiev, A. A. (1974). Psycholinguistic problems of mass communication. Science, 46-48.

Lippman, W. (2004). Public opinion. In-t Fonda 'Public Opinion', 384

Lukyanova, S. P. (2011). The method of investigating the individual life scenario. South Ural State University. 4(3), 7

Menlibekova, G. Zh. (2001). Social competence, essence, structure, content. Higher School of Kazakhstan. No. 4.

Mohd Najid, N., Tze Kiong, T., Che' Rus, R., \& Budiman, H. (2019). A Needs analysis on the development of problem based learning module for the microcontroller subject at Vocational College. Asian Journal of Assessment in Teaching and Learning, 9(2), 43-53.

Mokshein, S. E. M., Lebar, O., Yunus, J. Y., Rahmat, A., Dollah, M. U., Muhammad, A., Mansor, N. A., Mahmood, A., \& Noor, N. M. (2015). Development and Validation of Assessment Practice Inventory for Teacher Educators. Asian Journal of Assessment in Teaching and Learning, 5, 25-43.

Morris, C. W. (1977). Pragmatic semiotics and theory of action. With an introduction, (ed.) A. Eschbach. Suhrkamp

Nikitina, E. Yu., \& Mishanova O. G. (2011). Scientific and methodological concept of pedagogical management of communicative education of elementary schoolchildren: methodology and theory .MANPO, 145

Orlova, E. A. (1994). Introduction to social and cultural anthropology. Publishing House of MSIC, 214

Pierce, C. S. (1977). Semiotics and Significs. (Ed Charles Hardwick). Indiana University Press.

Pratama, H., Azman, M. N. A., Kassymova, G. K., \& Duisenbayeva, S. S. (2020). The Trend in Using Online Meeting Applications for Learning During the Period of Pandemic COVID-19: A Literature Review. Journal of Innovation in Educational and Cultural Research, 1(2), 58-68. https://doi.org/10.46843/jiecr.v1i2.15

Umberto, E. (1976). A Theory of Semiotics. Indiana University Press

Ravkin, Z. I. (1995). The development of education in Russia: new value guidelines orientation. Pedagogy. No. $5,15-23$.

Rozov, N. S. (1992). The structure of civilization and trends in world development. Publishing House NSU, 214

Rubinstein, S. L. (1958). About thinking and ways of its research. monograph. Science, 235

Silverblatt, A. A., \& Enright Eliceiri, E. M. (1997). Dictionary of Media Literacy. Greenwood Press, 234

Smirnov, S. D. (2005). Pedagogy and psychology of higher education: from activity to the individual. Academy, 400

Smirnova, L. N. (2004). Ways of enriching future teachers' speech culture. Innovative processes in education: Mater. (VIII international scientific-practical conference "Innovative processes in education" (April 22-23, 2004)), 182-186.

Treumann, K. P., Sander, U., \& Meister, D. (2007). Media use Of Young People. Media use and media competence. Wiesbaden. 808

Tugarinov, V. P. (1960). On the values of life and culture. Publishing house of Leningrad State University, 156 
Turgunbaeva, B. A., \& Tazhenova, G .S. (2018). Media competence is a quality necessary for a person to act freely in the information and new digital space. Kazakh National Pedagogical University named after Abai. (International Forum of the Eurasian Association of Pedagogical Universities 'Problems of Continuing Pedagogical Education: Traditions and Innovations')

Weber, M. (1994). Image of society. Lawyer 